\title{
Factors Associated with Choice of Career in Family Medicine Among Junior Doctors in Oman
}

*Asma Ali Al-Salmani, ${ }^{1}$ Asma Al-Shidhani, ${ }^{1}$ Najlaa Jaafar, ${ }^{2}$ Abdulaziz Al-Mahrezi ${ }^{1}$

$$
\text { العوامل المرتبطة باختيار المسار الوظيفي في طب الأسرة بين الأطباء المبتدئين في }
$$

$$
\text { أسماء علي السلمانية، أسماء الشيذانية، نجلاء جعفر، عبدالعزيز الدحرزي }
$$

ABSTRACT: Objectives: The number of family physicians in Oman is far below that recommended by the World Health Organization. This study aimed to determine factors influencing junior doctors' choice of a career in family medicine. Methods: This cross-sectional study was conducted between March and June 2018 and targeted applicants to Oman Medical Specialty Board residency programmes during the 2018-2019 academic year. Applicants were grouped according to their choice of either family medicine $(n=64)$ or other specialities $(n=81)$. A self-administered questionnaire was utilised to compare the applicants' sociodemographic characteristics, factors influencing their choice of career and their Myers-Briggs Type Indicator ${ }^{\circledR}$ (MBTI) personality traits. Results: A total of 52 family medicine and 43 other residency applicants participated in the study (response rates: $81.3 \%$ and $53.1 \%$, respectively). Most family medicine applicants were female (86.5\%), married (65.4\%) and resided in rural areas (73.1\%); moreover, $19.2 \%$ were $\geq 30$ years of age. Overall, emphasis on continuity of care, opportunity to deal with a variety of medical problems, the ability to use a wide range of skills and knowledge, early exposure to the discipline, opportunity to teach and perform research and the influence of family or friends were important factors in determining choice of a career in family medicine. Moreover, the MBTI analysis revealed that family medicine applicants were commonly extroverted-sensing-thinkingjudging personality types. Conclusion: Knowledge of the factors influencing career choice among junior doctors may be useful in determining future admission policies in order to increase the number of family physicians in Oman.

Keywords: Career Choice; Internship and Residency; Medical Specialty; Family Practice; Family Physicians; MyersBriggs Type Indicator; Oman.

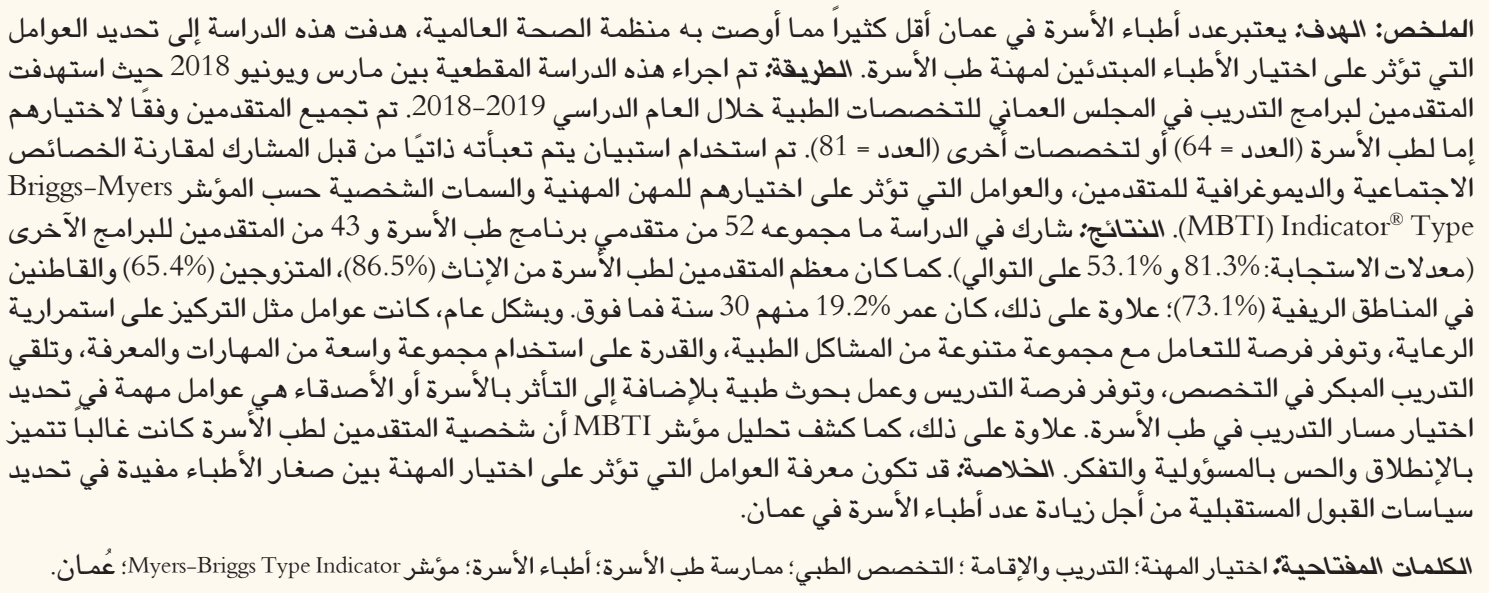

\footnotetext{
AdVAnCES IN KNOWLEDGE

This study evaluates factors influencing choice of a career in family medicine compared with other specialties among Omani junior doctors applying to Oman Medical Specialty Board (OMSB) residency programmes

Various factors were found to predict choice of a career in family medicine including age, gender, marital status and place of residence. Moreover, applicants to the OMSB family medicine residency programme highlighted continuity of care, the opportunity to deal with a variety of medical problems, the ability to use a wide range of skills and knowledge and early exposure to the discipline as important influences on their choice of specialty.
}

\section{Application to Patient Care}

The findings of this study can be used by educators and OMSB administrators to modify admission policies in order to encourage selection of this medical specialty and address the severe shortage of family physicians in Oman.

${ }^{1}$ Department of Family Medicine E Public Health, Sultan Qaboos University Hospital, Muscat, Oman; ${ }^{2}$ Programme Director, Family Medicine Residency Programme, Oman Medical Specialty Board, Muscat, Oman

*Corresponding Author's e-mail: asmaa_9988@hotmail.com 
$\mathrm{U}$ SING A COMMUNITY-ORIENTED AND COLLABorative approach, family physicians provide comprehensive healthcare services to individuals and families throughout the course of their lifetime including a wide spectrum of diagnostic, treatment, maintenance, preventative, rehabilitative and palliative healthcare services. ${ }^{1,2}$ In order to meet universal health coverage targets by 2030, the World Health Organization (WHO) Regional Office for the Eastern Mediterranean (EMRO), together with the World Organization of National Colleges, Academies and Academic Associations of General Practitioners/ Family Physicians (WONCA), recommend that a minimum of three family physicians be employed per 10,000 individuals in the population. ${ }^{2}$

In Oman, family medicine was first recognised as a unique medical speciality in 1987 at the College of Medicine \& Health Sciences at Sultan Qaboos University in Muscat. $^{3}$ Under the Oman Medical Specialty Board (OMSB), a four-year postgraduate training programme was established in 1994 and subsequently recognised by the Royal College of General Practitioners in 2001 and accredited by the Accreditation Council for Graduate Medical Education-International in 2017.3.4 However, as of 2015, Oman had an average of 0.4 family physicians per 10,000 individuals, a number far below that recommended by the WONCA and WHO EMRO. ${ }^{2}$

Other countries have reported similar shortages of family physicians in their workforce. ${ }^{5,6}$ Few junior doctors and medical students select family medicine as their top choice; for instance, the rate of selection of this specialty among Canadian medical graduates dropped from 40\% in 1982 to $32 \%$ in 2010, falling as low as $23 \%$ in some schools. ${ }^{7}$ In addition, a national survey of 39 medical schools in France indicated that the level of interest in primary care specialities was only 20\%. ${ }^{8}$ In southern Saudi Arabia, Mehmood et al. reported that the preferred specialty choices of medical students were surgery, internal medicine, paediatrics, orthopaedics and ophthalmology. ${ }^{9}$ Another study from eastern Saudi Arabia found that only 9\% of medical students and interns selected family medicine as a career choice in $2014 .^{10}$

In light of these trends, medical education institutions and administrators have sought to identify factors which influence career choice among junior doctors in order to determine potential strategies to increase interest in this specialty. In Canada, Gill et al. identified various factors-such as emphasis on continuity of care, length of residency, influence of family, friends or community and preference for working in a rural community-as factors significantly associated with the selection of family medicine compared to other specialties. ${ }^{7}$ Other factors have also been found to predict this choice of specialty, including being female, older, engaged, having a lower interest in research, an increased desire for short postgraduate training and a lower preference for medical versus social problems. ${ }^{711-16}$

To the best of the authors' knowledge, no studies have yet determined factors influencing the selection of family medicine as a career choice in Oman. As such, this study aimed to identify the factors influencing Omani junior doctors in the selection of family medicine as opposed to other specialities when applying to residency programmes. These findings could be useful for strengthening OMSB residency programmes and determining admission policies in order to encourage interest in this specialty and increase the number of family physicians in Oman.

\section{Methods}

This cross-sectional study was conducted between March and June 2018 at the OMSB. The entire cohort of applicants to OMSB residency programmes for the 2018-2019 academic year were contacted directly and invited to participate in the study. The applicants were subsequently divided into two groups according to their choice of career in either family medicine ( $\mathrm{n}=$ $64)$ or other specialities $(n=81)$.

A three-part self-administered English-language questionnaire was used to collect data. The first part determined the participants' sociodemographic characteristics including age, gender, parental education level, presence of family or friends in family medicine or other medical fields and involvement in community programmes, volunteer work or research. The second part assessed factors influencing choice of speciality based on a previously validated survey from the University of Alberta in Canada. ${ }^{7}$ Applicants were asked to rate the level of importance of each item on a scale from 1 to 5 in terms of influencing their career choice, with 1 being very unimportant and 5 being very important. ${ }^{7}$ The third part of the questionnaire aimed to determine personality type according to the Myers-Briggs Type Indicator ${ }^{\circledR}$ (MBTI) personality inventory. ${ }^{17}$

The primary outcome of the study was factors influencing the choice of family medicine compared to other specialties among junior doctors. The secondary outcome was the most common personality type among those who selected family medicine as their career specialty. For the purposes of the analysis, participants' responses to the second part of the 
questionnaire were grouped as either important (i.e. responses of somewhat important and very important) or not important (i.e. responses of very unimportant, somewhat unimportant and neither unimportant nor important). ${ }^{7}$

Data analysis was performed using the Statistical Package for the Social Sciences (SPSS), Version 25.0 (IBM Corp., Armonk, New York, USA). The results were presented using descriptive statistics. Means and standard deviations were reported for continuous variables, while categorical variables were presented as frequencies and percentages. The association of the independent variables with outcome variables was calculated using non-parametric Kruskal-Wallis and Mann-Whitney-U tests. The level of two-tailed significance was set at $P<0.050$.

The protocol for this study was approved by the Research Ethics Committee of the OMSB (REC/03/2018). Informed verbal consent was obtained from all applicants prior to their participation in the study. The individual contact details of the applicants were used with permission from the OMSB Admissions Office.

\section{Results}

A total of 52 family medicine applicants and 43 applicants from other OMSB residency programmes agreed to take part in the study (response rates: 81.3\% and 53.1\%, respectively). Compared to those in other specialties, applicants to the family medicine programme were significantly more likely to be 30 years of age or older (19.2\% versus $0 \% ; P=0.026)$, female (86.5\% versus 51.2\%; $P<0.001)$, married $(65.4 \%$ versus $37.2 \% ; P=0.021$ ) and reside in rural areas (73.1\% versus $67.4 \% ; P=0.005)$. In addition, family medicine applicants were significantly more likely to have a family member or close friend practising family medicine $(61.5 \%$ versus $2.3 \% ; P<0.001)$ or other medical specialties $(82.7 \%$ versus $41.9 \%$; $P<0.001)$ [Table 1].

Applicants rated the perceived importance of factors contributing to their choice of career. The vast majority of family medicine applicants believed the following factors to be important when it came to choosing their preferred specialty: the ability to use a wide range of skills and knowledge in patient care (92.3\%), emphasis on continuity of care (90.4\%), the opportunity to deal with a variety of medical problems (90.4\%) and early exposure to the discipline (90.4\%). In contrast, the most important factors rated by applicants to other specialties were the opportunity to deal with a variety of medical problems (93\%), whether the specialty was compatible with their personality
Table 1: Sociodemographic characteristics of applicants to Oman Medical Specialty Board residency programmes $(\mathrm{N}=95)$

\begin{tabular}{|c|c|c|c|}
\hline \multirow[t]{2}{*}{ Characteristic } & \multicolumn{2}{|c|}{ n (\%) } & \multirow{2}{*}{$\begin{array}{c}P \\
\text { value }\end{array}$} \\
\hline & $\begin{array}{c}\text { Family } \\
\text { medicine } \\
(n=52)\end{array}$ & $\begin{array}{c}\text { Other medical } \\
\text { specialties } \\
(\mathrm{n}=43)\end{array}$ & \\
\hline \multicolumn{3}{|l|}{ Age in years } & 0.026 \\
\hline$<30$ & $42(80.8 \%)$ & $43(100)$ & \\
\hline$\geq 30$ & $10(19.2 \%)$ & $0(0)$ & \\
\hline \multicolumn{3}{|l|}{ Gender } & $<0.001$ \\
\hline Female & $45(86.5)$ & $22(51.2)$ & \\
\hline Male & $7(13.5)$ & $21(48.8)$ & \\
\hline \multicolumn{3}{|l|}{ Marital status } & 0.021 \\
\hline Single & $18(34.6)$ & $27(62.8 \%)$ & \\
\hline Married & $34(65.4)$ & $16(37.2 \%)$ & \\
\hline $\begin{array}{l}\text { Divorced/ } \\
\text { widowed }\end{array}$ & $0(0)$ & $0(0)$ & \\
\hline \multicolumn{3}{|l|}{ Number of children } & 0.521 \\
\hline 0 & $34(65.4)$ & $30(69.8)$ & \\
\hline$<2$ & $13(25)$ & $13(30.2)$ & \\
\hline $2-3$ & $5(9.6)$ & $0(0)$ & \\
\hline \multicolumn{3}{|c|}{ Maternal education level } & 0.009 \\
\hline Illiterate & $21(40.4)$ & $33(76.7)$ & \\
\hline School & $23(44.2)$ & $7(16.3)$ & \\
\hline College & $4(7.7)$ & $3(7.0)$ & \\
\hline Postgraduate & $4(7.7)$ & $0(0)$ & \\
\hline \multicolumn{3}{|c|}{ Paternal education level } & $<0.001$ \\
\hline Illiterate & $2(3.8)$ & $24(55.8)$ & \\
\hline School & $32(61.5)$ & $5(11.6)$ & \\
\hline College & $9(17.3)$ & $3(7)$ & \\
\hline Postgraduate & $9(17.3)$ & $11(25.6)$ & \\
\hline \multicolumn{3}{|l|}{ Place of residence } & 0.005 \\
\hline Urban (Muscat) & $14(26.9)$ & $14(32.6)$ & \\
\hline $\begin{array}{l}\text { Rural (other } \\
\text { regions) }\end{array}$ & $38(73.1)$ & $29(67.4)$ & \\
\hline \multicolumn{3}{|c|}{ Monthly income in OMR } & 0.020 \\
\hline$<1,000$ & $12(23.1)$ & $26(60.5)$ & \\
\hline $1,000-3,000$ & $40(76.9)$ & $17(39.5)$ & \\
\hline$>3,000$ & $0(0)$ & $0(0)$ & \\
\hline \multicolumn{3}{|c|}{$\begin{array}{l}\text { Presence of a family member or friend in family } \\
\text { medicine }\end{array}$} & $<0.001$ \\
\hline Yes & $32(61.5)$ & $1(2.3 \%)$ & \\
\hline No & $20(38.5)$ & $42(97.7)$ & \\
\hline
\end{tabular}


Table 1 (cont'd): Sociodemographic characteristics of applicants to Oman Medical Specialty Board residency programmes $(\mathrm{N}=95)$

\begin{tabular}{|c|c|c|c|}
\hline \multirow[t]{2}{*}{ Characteristic } & \multicolumn{2}{|c|}{ n (\%) } & \multirow{2}{*}{$\begin{array}{c}P \\
\text { value }\end{array}$} \\
\hline & $\begin{array}{l}\text { Family } \\
\text { medicine } \\
(n=52)\end{array}$ & $\begin{array}{l}\text { Other medical } \\
\text { specialties } \\
(n=43)\end{array}$ & \\
\hline \multicolumn{3}{|c|}{$\begin{array}{l}\text { Presence of a family member or friend in other } \\
\text { medical specialties }\end{array}$} & $<0.001$ \\
\hline Yes & $43(82.7)$ & $18(41.9)$ & \\
\hline No & $9(17.3)$ & $25(58.1)$ & \\
\hline \multicolumn{3}{|c|}{ Involvement in community programmes } & 0.660 \\
\hline Yes & $38(73.1)$ & $31(72.1)$ & \\
\hline No & $14(26.9)$ & $12(27.9)$ & \\
\hline \multicolumn{3}{|c|}{ Involvement in volunteer work } & 0.650 \\
\hline Yes & $39(75)$ & $31(72.1)$ & \\
\hline No & $13(25)$ & $12(27.9)$ & \\
\hline \multicolumn{3}{|c|}{ Involvement in research } & 0.220 \\
\hline Yes & $42(80.8)$ & $34(79.1)$ & \\
\hline No & $10(19.2)$ & $9(20.9)$ & \\
\hline
\end{tabular}

$O M R=$ Omani riyals

(93\%) and the ability to master a small set of skills and be an 'expert' (93\%).

There were statistically significant differences between family medicine applicants and those in other programmes with regards to the perceived importance of emphasis on continuity of care $(90.4 \%$ versus $48.8 \%$; $P<0.001$ ), early exposure to the discipline $(90.4 \%$ versus $37.2 \% ; P<0.001)$, opportunity for research (86.5\% versus $51.2 \% ; P<0.001$ ), previous exposure to primary care practice $(84.6 \%$ versus $0 \% ; P<0.001)$, opportunity to teach $(80.8 \%$ versus $34.9 \%$; $P<0.001)$, the influence of family or friends $(71.2 \%$ versus $9.3 \%$; $P<0.001)$ and the intellectual content of the discipline (75\% versus $30.2 \% ; P<0.001$ ).

In contrast, fewer applicants to the family medicine programme rated income potential (51.9\% versus 100\%; $P<0.001$ ) and perceived prestige (59.6\% versus $81.4 \%$; $P=0.020$ ) to be unimportant during career selection compared to applicants in other specialties. Regardless of specialty, most of the applicants reported that working hours/lifestyle, the length of the residency programme and a positive experience with a teacher or clinician of the specialty were important factors in their selection [Table 2]. Compared to other personality archetypes within the MBTI personality inventory, applicants to family medicine were most commonly extroverted-sensingthinking-judging (ESTJ) types [Figure 1].
Table 2: Importance of factors influencing career choice" among applicants to Oman Medical Specialty Board residency programmes $(\mathrm{N}=95)$

\begin{tabular}{|c|c|c|c|c|c|}
\hline \multirow[t]{3}{*}{ Item } & \multicolumn{4}{|c|}{ Perceived importance, $\mathrm{n}(\%)$} & \multirow{3}{*}{$\begin{array}{c}P \\
\text { value }\end{array}$} \\
\hline & \multicolumn{2}{|c|}{$\begin{array}{l}\text { Family } \\
\text { medicine (n } \\
=52)\end{array}$} & \multicolumn{2}{|c|}{$\begin{array}{l}\text { Other medical } \\
\text { specialties ( } \mathrm{n} \\
=43)\end{array}$} & \\
\hline & UI & I & UI & I & \\
\hline $\begin{array}{l}\text { Income } \\
\text { potential }\end{array}$ & $\begin{array}{c}27 \\
(51.9)\end{array}$ & $\begin{array}{c}25 \\
(48.1)\end{array}$ & $\begin{array}{c}43 \\
(100)\end{array}$ & $0(0)$ & $<0.001$ \\
\hline $\begin{array}{l}\text { Perceived } \\
\text { prestige }\end{array}$ & $\begin{array}{c}31 \\
(59.6)\end{array}$ & $\begin{array}{c}21 \\
(40.4)\end{array}$ & $\begin{array}{c}35 \\
(81.4)\end{array}$ & $\begin{array}{c}8 \\
(18.6)\end{array}$ & 0.020 \\
\hline $\begin{array}{l}\text { Emphasis on } \\
\text { procedural } \\
\text { skills }\end{array}$ & $\begin{array}{c}7 \\
(13.5)\end{array}$ & $\begin{array}{c}45 \\
(86.5)\end{array}$ & $\begin{array}{c}13 \\
(30.2)\end{array}$ & $\begin{array}{c}30 \\
(69.8)\end{array}$ & 0.046 \\
\hline $\begin{array}{l}\text { Specialty } \\
\text { compatible } \\
\text { with } \\
\text { personality }\end{array}$ & $\begin{array}{c}7 \\
(13.5)\end{array}$ & $\begin{array}{c}45 \\
(86.5)\end{array}$ & $3(7)$ & $\begin{array}{c}40 \\
(93)\end{array}$ & 0.305 \\
\hline $\begin{array}{l}\text { Opportunity } \\
\text { to teach }\end{array}$ & $\begin{array}{c}10 \\
(19.2)\end{array}$ & $\begin{array}{c}42 \\
(80.8)\end{array}$ & $\begin{array}{c}28 \\
(65.1)\end{array}$ & $\begin{array}{c}15 \\
(34.9)\end{array}$ & $<0.001$ \\
\hline $\begin{array}{l}\text { Preference/ } \\
\text { influence } \\
\text { of family, } \\
\text { friends or } \\
\text { community }\end{array}$ & $\begin{array}{c}15 \\
(28.8)\end{array}$ & $\begin{array}{c}37 \\
(71.2)\end{array}$ & $\begin{array}{c}39 \\
(90.7)\end{array}$ & $\begin{array}{c}4 \\
(9.3)\end{array}$ & $<0.001$ \\
\hline $\begin{array}{l}\text { Perceived } \\
\text { intellectual } \\
\text { content of } \\
\text { discipline }\end{array}$ & $\begin{array}{c}13 \\
(25)\end{array}$ & $\begin{array}{c}39 \\
(75)\end{array}$ & $\begin{array}{c}30 \\
(69.8)\end{array}$ & $\begin{array}{c}13 \\
(30.2)\end{array}$ & $<0.001$ \\
\hline $\begin{array}{l}\text { Opportunity } \\
\text { for research }\end{array}$ & $\begin{array}{c}7 \\
(13.5)\end{array}$ & $\begin{array}{c}45 \\
(86.5)\end{array}$ & $\begin{array}{c}21 \\
(48.8)\end{array}$ & $\begin{array}{c}22 \\
(51.2)\end{array}$ & $<0.001$ \\
\hline $\begin{array}{l}\text { Opportunity } \\
\text { to work on } \\
\text { challenging } \\
\text { cases }\end{array}$ & $\begin{array}{c}10 \\
(19.2)\end{array}$ & $\begin{array}{c}42 \\
(80.8)\end{array}$ & $6(14)$ & $\begin{array}{c}37 \\
(86)\end{array}$ & 0.494 \\
\hline $\begin{array}{l}\text { Opportunity } \\
\text { to work } \\
\text { on acute } \\
\text { medical } \\
\text { problems }\end{array}$ & $\begin{array}{c}7 \\
(13.5)\end{array}$ & $\begin{array}{c}45 \\
(86.5)\end{array}$ & $\begin{array}{c}10 \\
(23.3)\end{array}$ & $\begin{array}{c}33 \\
(76.7)\end{array}$ & 0.215 \\
\hline $\begin{array}{l}\text { Emphasis on } \\
\text { continuity of } \\
\text { care }\end{array}$ & $\begin{array}{c}5 \\
(9.6)\end{array}$ & $\begin{array}{c}47 \\
(90.4)\end{array}$ & $\begin{array}{c}22 \\
(51.2)\end{array}$ & $\begin{array}{c}21 \\
(48.8)\end{array}$ & $<0.001$ \\
\hline $\begin{array}{l}\text { Opportunity } \\
\text { to deal with } \\
\text { a variety } \\
\text { of medical } \\
\text { problems }\end{array}$ & $\begin{array}{c}5 \\
(9.6)\end{array}$ & $\begin{array}{c}47 \\
(90.4)\end{array}$ & $3(7)$ & $\begin{array}{c}40 \\
(93)\end{array}$ & 0.645 \\
\hline $\begin{array}{l}\text { Early } \\
\text { exposure } \\
\text { to the } \\
\text { discipline }\end{array}$ & $\begin{array}{c}5 \\
(9.6)\end{array}$ & $\begin{array}{c}47 \\
(90.4)\end{array}$ & $\begin{array}{c}27 \\
(62.8)\end{array}$ & $\begin{array}{c}16 \\
(37.2)\end{array}$ & $<0.001$ \\
\hline $\begin{array}{l}\text { Length of } \\
\text { residency }\end{array}$ & $\begin{array}{c}13 \\
(25)\end{array}$ & $\begin{array}{c}39 \\
(75)\end{array}$ & $\begin{array}{c}13 \\
(30.2)\end{array}$ & $\begin{array}{c}30 \\
(69.8)\end{array}$ & 0.569 \\
\hline $\begin{array}{l}\text { Ability to } \\
\text { use a wide } \\
\text { range of } \\
\text { skills and } \\
\text { knowledge }\end{array}$ & $\begin{array}{c}4 \\
(7.7)\end{array}$ & $\begin{array}{c}48 \\
(92.3)\end{array}$ & $\begin{array}{c}10 \\
(23.3)\end{array}$ & $\begin{array}{c}33 \\
(76.7)\end{array}$ & 0.033 \\
\hline
\end{tabular}

being very important. 
Table 2 (cont'd): Importance of factors influencing career choice* among applicants to Oman Medical Specialty Board residency programmes $(\mathrm{N}=95)$

\begin{tabular}{|c|c|c|c|c|c|}
\hline \multirow[t]{3}{*}{ Item } & \multicolumn{4}{|c|}{ Perceived importance, n (\%) } & \multirow{3}{*}{$\begin{array}{c}P \\
\text { value }\end{array}$} \\
\hline & \multicolumn{2}{|c|}{$\begin{array}{l}\text { Family } \\
\text { medicine (n } \\
=52)\end{array}$} & \multicolumn{2}{|c|}{$\begin{array}{l}\text { Other medical } \\
\text { specialties (n } \\
=43)\end{array}$} & \\
\hline & UI & I & UI & I & \\
\hline $\begin{array}{l}\text { Working } \\
\text { hours/ } \\
\text { lifestyle after } \\
\text { completion } \\
\text { of training }\end{array}$ & $\begin{array}{c}12 \\
(23.1)\end{array}$ & $\begin{array}{c}40 \\
(76.9)\end{array}$ & $\begin{array}{c}7 \\
(16.3)\end{array}$ & $\begin{array}{c}36 \\
(83.7)\end{array}$ & 0.410 \\
\hline $\begin{array}{l}\text { Previous } \\
\text { exposure to } \\
\text { primary care } \\
\text { practice }\end{array}$ & $\begin{array}{c}8 \\
(15.4)\end{array}$ & $\begin{array}{c}44 \\
(84.6)\end{array}$ & $\begin{array}{c}43 \\
(100)\end{array}$ & $0(0)$ & $<0.001$ \\
\hline
\end{tabular}

$U I=$ unimportant $I=$ important. "According to self-rated responses to a previously validated survey from the University of Alberta, Canada. ${ }^{1 .}$ Each item was scored from 1 to 5, with 1 being very unimportant and 5 being very important.

\section{Discussion}

As demonstrated by the WONCA and WHO EMRO report, there is an urgent need to address the shortage of approximately 185,497 family physicians in the Middle Eastern region. ${ }^{2}$ Nevertheless, the selection of family medicine as a career choice by junior doctors remains a complex process affected by many factors related both to individual residency programmes, the healthcare system and the sociodemographic characteristics and personalities of the doctors themselves. Research examining these factors has been conducted in several countries for the purposes of modifying existing policy-building and decisionmaking processes in order to encourage more doctors to choose this specialty. $7,9,12$

In the current study, applicants to the OMSB family medicine residency programme were significantly more likely to be female, married and over 30 years of age. It is possible that married women prefer specialties in which they can have part-time duties so that they can more easily take care of their families. Similarly, a study conducted in Canada involving 16 medical schools found that being older and engaged were variables which predicted selection of a career in family medicine. ${ }^{6}$ Likewise, more female medical students and interns in Saudi Arabia selected family medicine as their top choice compared to any other specialty. ${ }^{10}$ In addition, family medicine applicants in the present study were significantly more likely to be from rural areas. This might be due to cultural differences, the presence of friends or family or the lack of family physicians in these areas compared to the capital. Other studies have reported comparable results. ${ }^{13,14,18}$ As such, it is possible that increasing

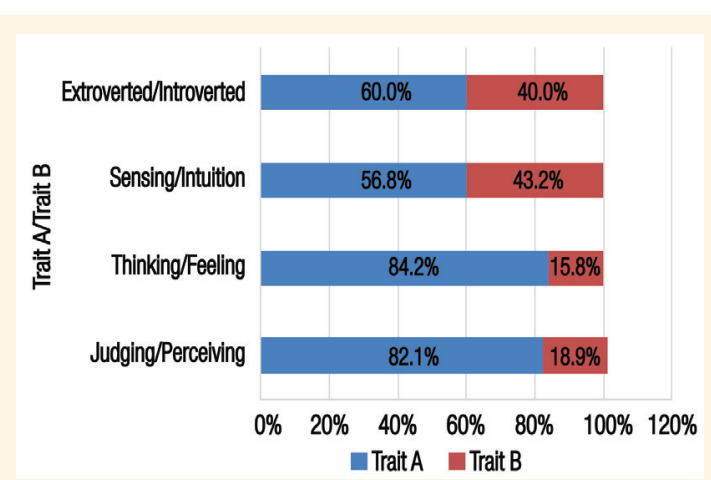

Figure 1: Frequency of Myers-Briggs Type Indicator ${ }^{\circledR}$ personality traits among applicants to Oman Medical Specialty Board residency programme $(\mathrm{N}=95)$.

admission rates for female doctors from rural areas would help to eventually increase the number of family physicians in Oman.

The effect of role-modelling was apparent in the current study, as the majority of applicants rated a positive experience with a clinician/teacher as an important factor in their selection, regardless of specialty. Similar findings have also been reported in other studies. ${ }^{6,7,10,15}$ Having a family member or close friend in the field of family medicine or other medical specialties can also have an effect on career selection., ${ }^{71,14-16}$ In the present study, over half of this group had a friend or family member involved in this field; moreover, the influence of family, friends or community was perceived to be of great importance when making a career decision overall. Generally, the core principles of family medicine as a specialty were highly rated by the family medicine applicants and included continuity of care, the ability to use a wide range of skills and knowledge and early exposure to the discipline. Such factors are programme-specific and have also been rated highly elsewhere around the world. ${ }^{7,18,19}$ Therefore, enabling the admission of junior doctors who have previous exposure to the field might add to the number who choose to become family physicians in future.

Interestingly, family medicine applicants in the current study reported being greatly influenced by the opportunity to teach and perform research; this conflicts with the findings of other studies. ${ }^{6,720}$ This difference might be due to the growing need for general medical research in this region, as well as research specific to the field of family medicine. In addition, just over half of the family applicants rated income potential and perceived prestige as unimportant factors; this might be because most family medicine applicants were female and thus might be more concerned about their future quality of work, career development and time spent away from their families. This finding was also observed by other researchers. ${ }^{21}$ 
Personality may play a role when it comes to career choice and the selection of a medical specialty. However, studies which have investigated the effect of personality type using the MBTI personality inventory have revealed mixed results. ${ }^{22}$ The MBTI inventory is used to assign one of 16 unique personality archetypes based on a sliding scale in four dichotomous categories: (1) extraversion versus introversion; (2) sensing versus intuition; (3) thinking versus feeling; and (4) judgement versus perception. ${ }^{17}$ In the present study, the predominant personality archetype among those who selected family medicine as a specialty was ESTJ. This is similar to that observed in an older study conducted in 1976. ${ }^{23}$ However, more recent studies have since found that the family medicine specialty is chosen more frequently by those who score highly in the feeling trait compared to the thinking trait. ${ }^{22,24}$

Certain limitations were present within the current study. Only junior doctors who applied to different OMSB residency programmes were targeted; as such, the study did not include the perspectives of medical students which would be an important addition to strengthen interest in the family medicine programme and encourage admissions. Additionally, the survey might not have addressed all factors influencing career choice; moreover, as the questionnaire was not originally designed for this population, some sociocultural factors unique to Oman might not have been considered. However, this limitation was partially resolved by including an option for "other" within the survey.

\section{Conclusion}

According to international recommendations, there is a national shortage of family physicians in Oman. This study identified various factors which influenced the selection of family medicine as a residency specialty among junior doctors including an emphasis on continuity of care, the ability to use a variety of skills and knowledge and early exposure to the discipline. In addition, family medicine applicants were significantly more likely to be older, female, married and reside in rural areas compared to those in other specialties. These findings may be useful in modifying admission policies and encouraging interest in this choice of specialty among future doctors in Oman.

\section{ACKNOWLEDGEMENT}

Permission was received from the University of Alberta to use the survey assessing factors influencing choice of speciality.

\section{CONFLICT OF INTEREST}

The authors declare no conflicts of interest.

\section{FUNDING}

No funding was received for this study.

\section{References}

1. Boelen C. Improving Health Systems: The contribution of family medicine - A guidebook. Singapore: World Organization of National Colleges, Academies and Academic Association of General Practitioners/Family Physicians, 2002.

2. World Health Organization Regional Office for the Eastern Mediterranean. Scaling up family practice: Progression towards universal health coverage. From: https://applications.emro. who.int/docs/RC_technical_papers_2016_tech_disc_1_19022_ EN.pdf?ua=1\&ua=1 Accessed: $\operatorname{Jan} 2020$

3. Al-Shafaee M. Family medicine practice in Oman: Present and future. Sultan Qaboos Univ Med J 2009; 9:116-18.

4. Accreditation Council for Graduate Medical EducationInternational. International benchmarking through accreditation drives Oman Medical Specialty Board (OMSB) to meet worldwide standards. From: www.acgme-i.org/Whatis-Accreditation/Accreditation-Stories/Accreditation-StoryDetails/ArticleID/3 Accessed: Jan 2020.

5. Puertas EB, Arósquipa C, Gutiérrez D. Factors that influence a career choice in primary care among medical students from high-, middle-, and low-income countries: A systematic review. Rev Panam Salud Publica 2013; 34:351-8.

6. Scott I, Gowans M, Wright B, Brenneis F, Banner S, Boone J. Determinants of choosing a career in family medicine. CMAJ 20110; 183:E1-8. https://doi.org/10.1503/cmaj.091805.

7. Gill H, McLeod S, Duerksen K, Szafran O. Factors influencing medical students' choice of family medicine: Effects of rural versus urban background. Can Fam Physician 2012; 58:e649-57.

8. Lefevre JH, Roupret M, Kerneis S, Karila L. Career choices of medical students: A national survey of 1780 students. Med Educ 2010; 44:603-12. https://doi.org/10.1111/j.13652923.2010.03707.x

9. Mehmood SI, Kumar A, Al-Binali A, Borleffs JC. Specialty preferences: Trends and perceptions among Saudi undergraduate medical students. Med Teach 2012; 34:S51-60. https://doi.org/10.3109/0142159x.2012.656753.

10. Alshahrani M, Dhafery B, Al Mulhim M, Alkhadra F, Al Bagshi D, Bukhamsin N. Factors influencing Saudi medical students and interns' choice of future specialty: A self-administered questionnaire. Adv Med Educ Pract 2014; 397-402. https://doi. org/10.2147/amep.s69152.

11. Senf JH, Campos-Outcalt D, Watkins AJ, Bastacky S, Killian C. A systematic analysis of how medical school characteristics relate to graduates' choices of primary care specialties. Acad Med 1997; 72:524-33. https://doi.org/10.1097/00001888-19970 6000-00020.

12. Kassebaum DG, Szenas PL, Schuchert MK. Determinants of the generalist career intentions of 1995 graduating medical students. Acad Med 1996; 71:198-209. https://doi. org/10.1097/00001888-199602000-00030.

13. Rabinowitz HK, Diamond JJ, Markham FW, Santana AJ. The relationship between entering medical students' backgrounds and career plans and their rural practice outcomes three decades later. Acad Med 2012; 87:493-7. https://doi.org/10.10 97/acm.0b013e3182488c06. 
14. Kondalsamy-Chennakesavan S, Eley DS, Ranmuthugala G, Chater AB, Toombs MR, Darshan D, et al. Determinants of rural practice: Positive interaction between rural background and rural undergraduate training. Med J Aust 2015; 202:41-45. https://doi.org/10.5694/mja14.00236.

15. Borges NJ, Manuel RS, Duffy RD, Fedyna D, Jones BJ. Influences on specialty choice for students entering person-oriented and technique-oriented specialties. Med Teach 2009; 31:1086-8. https://doi.org/10.3109/01421590903183787.

16. Stagg P, Greenhill J, Worley PS. A new model to understand the career choice and practice location decisions of medical graduates. Rural Remote Health 2009; 9:1245. https://doi. org $/ 10.22605 /$ rrh1245.

17. The Myers \& Briggs Foundation. MBTI ${ }^{\circ}$ basics. From: www. myersbriggs.org/my-mbti-personality-type/mbti-basics/ Accessed: Jan 2020.

18. Alavi M, Ho T, Stisher C, Richardson E, Kelly C, McCrory KE, et al. Factors that influence student choice in family medicine: A national focus group. Fam Med 2019; 51:143-8. https://doi. org/10.22454/FamMed.2019.927833.
19. Hashim MJ. Principles of family medicine and general practice: Defining the five core values of the specialty. J Prim Health Care 2016; 8:283-7. https://doi.org/10.1071/hc16006.

20. Vanasse A, Orzanco MG, Courteau J, Scott S. Attractiveness of family medicine for medical students: Influence of research and debt. Can Fam Physician 2011; 57:e216-27.

21. Senf JH, Campos-Outcalt D, Kutob R. Factors related to the choice of family medicine: A reassessment and literature review. J Am Board Fam Pract 2003; 16:502-12. https://doi. org/10.3122/jabfm.16.6.502.

22. Prasad M. A test of Myers-Briggs type indicator in health professions: A literature review. Asian J Manag 2016; 7:297-306. https://doi.org/10.5958/2321-5763.2016.00045.7.

23. Myers IB, Davis JA. Relation of medical students' psychological type to their specialties twelve years later. Gainesville, Florida, USA: Educational Testing Service, 1976.

24. Mehmood SI, Khan MA, Walsh KM, Borleffs JC. Personality types and specialist choices in medical students. Med Teach 2013; 35:63-8. https://doi.org/10.3109/0142159x.2012.731104. 